\title{
Androgenic-anabolic steroid-induced body changes in strength athletes
}

Citation for published version (APA):

Hartgens, L. M. G., van Marken Lichtenbelt, W. D., Ebbing, S., Vollard, N., Rietjens, G. J. W. M., \&

Kuipers, H. (2001). Androgenic-anabolic steroid-induced body changes in strength athletes. Physician and Sportsmedicine, 29, 49-66. https://doi.org/10.3810/psm.2001.01.316

Document status and date:

Published: 01/01/2001

DOI:

10.3810/psm.2001.01.316

Document Version:

Publisher's PDF, also known as Version of record

Document license:

Taverne

Please check the document version of this publication:

- A submitted manuscript is the version of the article upon submission and before peer-review. There can be important differences between the submitted version and the official published version of record.

People interested in the research are advised to contact the author for the final version of the publication, or visit the DOI to the publisher's website.

- The final author version and the galley proof are versions of the publication after peer review.

- The final published version features the final layout of the paper including the volume, issue and page numbers.

Link to publication

\footnotetext{
General rights rights.

- You may freely distribute the URL identifying the publication in the public portal. please follow below link for the End User Agreement:

www.umlib.nl/taverne-license

Take down policy

If you believe that this document breaches copyright please contact us at:

repository@maastrichtuniversity.nl

providing details and we will investigate your claim.
}

Copyright and moral rights for the publications made accessible in the public portal are retained by the authors and/or other copyright owners and it is a condition of accessing publications that users recognise and abide by the legal requirements associated with these

- Users may download and print one copy of any publication from the public portal for the purpose of private study or research.

- You may not further distribute the material or use it for any profit-making activity or commercial gain

If the publication is distributed under the terms of Article $25 \mathrm{fa}$ of the Dutch Copyright Act, indicated by the "Taverne" license above, 


\section{The Physician and Sportsmedicine}

\section{Androgenic-Anabolic Steroid-Induced Body Changes in Strength Athletes}

Fred Hartgens, Wouter D. Van Marken Lichtenbelt, Spike Ebbing, Niels Vollaard, Gerard Rietjens \& Harm Kuipers

To cite this article: Fred Hartgens, Wouter D. Van Marken Lichtenbelt, Spike Ebbing, Niels Vollaard, Gerard Rietjens \& Harm Kuipers (2001) Androgenic-Anabolic Steroid-Induced Body Changes in Strength Athletes, The Physician and Sportsmedicine, 29:1, 49-66, DOI: 10.3810/ psm.2001.01.316

To link to this article: https://doi.org/10.3810/psm.2001.01.316

曲 Published online: 19 Jun 2015.

Submit your article to this journal

山 Article views: 75

Q View related articles $\asymp$

4 Citing articles: 2 View citing articles 준 


\title{
Androgenic-Anabolic Steroid-Induced Body Changes in Strength Athletes
}

\author{
Fred Hartgens, MD; Wouter D. Van Marken Lichtenbelt, PhD; Spike Ebbing, MSe; \\ Niels Vollaard, MSc; Gerard Rietjens, MSc; Harm Kuipers, MD, PhD
}

\section{ABSTRACT}

BACKGROUND: Some strength athletes use androgenic-anabolic steroids (AAS) to improve body dimensions, though the drugs' long- and short-term effects have not been definitively established.

OBJECTIVE: This study sought to investigate the short- and long-term effects of AAS self-administration on body dimensions and total and regional body composition.

DESIGH: This prospective, unblinded study involved 35 experienced male strength athletes: 19 AAS users (drugs were self-administered) and 16 nonuser controls engaged in their usual training regimens. At baseline, 8 weeks, and 6 weeks after AAS withdrawal (for AAS users) circumferences were measured at 10 sites, and skinfolds measured at 8 sites. To assess differences in AAS regimens, 9 subjects took AAS for 8 weeks (short-AAS) and 10 athletes took A.AS for 12 to 16 weeks (long-AAS). Body composition and anthropometry were assessed at baseline, at the end of AAS use, and 6 weeks later. Lean body mass (LBM) was calculated from body weight and percentage fat. Total and regional body composition was measured by dual-energy $\mathrm{x}$-ray absorptiometry.

RESULTS: AAS use increased users' body weight by $4.4 \mathrm{~kg}$ and LBM by $4.5 \mathrm{~kg}$, and produced increases in several circumferences. Percentage of fat decreased (17.0\% to $16.0 \%$ ), but fat mass remained unchanged. Changes persisted 6 weeks after drug withdrawal but were not less than those taken at 8 weeks. Bone-free lean mass of all regional body parts increased in subjects taking AAS, but fat mass was unaffected. Short- and long-term AAS users did not differ in any parameter measured at 8 weeks or after drug withdrawal.

CONCLUSION: In AAS users, 8 weeks of self-administered AAS increased body weight, lean body mass, and limb circumferences, but decreased percentage fat compared with controls. Changes remained 6 weeks after drug withdrawal, though for some measurements only partially. AAS stimulated the bone-free lean mass of all body parts, but it did not affect fat mass. Short-term and long-term AAS administration produced comparable effects.

he use of androgenic-anabolic steroids (AAS) in athletes seems to be widespread. As reported by laboratories accredited by the International Olympic Committee,' these drugs have been the most frequently detected substances in urine samples of athletes. AAS use by elite athletes is of great concern for national and international sports federations because the drugs give users an unfair advantage and produce potentially deleterious health effects. ${ }^{2.3}$ AAS use is not limited to elite

For CME, see www.physsportsmed.com/cme.htm beginning in February 2001 athletes, however, and may be more extensive among recreational and amateur strength athletes, even though the media devote less attention to use in these groups.

Strength athletes often progress to self-administration of AAS to increase muscle mass and strength. Weight lifters and power lifters strive primarily for strength, whereas bodybuilders train for optimal muscle mass and body dimensions. ${ }^{3}$ Consequently, in all strength athletes increased muscle mass is desirable. Only a few studies have investigated the effects of AAS on muscle mass and body dimensions. Unfortunately, data are equivocal, and many questions remain to be answered.

continued 
Our study sought answers to three questions: (1) Which body measurements and composition are altered in strength athletes when they use several AAS simultaneously? (2) Does self-administration of AAS exert distinct effects on the separate components of regional body composition? and (3) What impact does the duration of AAS use have on anthropometry and body composition?

\section{Methods}

Subjects and their AAS use. Strength athletes were recruited with advertisements at local gyms. Inclusion criteria were: male, at least 3 years of strength training experience, and age between 20 and 45 years. Candidates excluded were those who smoked or had hypertension, diabetes mellitus, liver disease or abnormal liver enzyme levels, hereditary hypercholesterolemia, elevated serum cholesterol levels $(>6.5 \mathrm{mmol} / \mathrm{L})$, or infertility. Before participating, all subjects completed a questionnaire containing questions about medical history, health status, training experience and status, nutrition, nutritional supplement use, and AAS use.

After the initial screening, each strength athlete underwent a full medical examination by a physician for evaluation of health status and to screen for possible missed exclusion criteria. During the examination, we provided extensive oral and written information about the study to each subject. All subjects signed an informed consent form approved by the Ethical Committee of Maastricht

Dr Hartgens is research and science coordinator at The Netherlands' Center for Doping Affairs in Capelle aan den IJssel, The Netherlands. Dr Van Marken Lichtenbelt is assistant professor in the department of human biology at Maastricht University, Mr Ebbing and Mr Vollaard were Masters students at The Netherlands Center for Doping Affairs in Capelle aan den IJSsel. Mr Rietjens is assistant research and science coordinator at The Netherlands Center for Doping Affairs in Capelle aan den IJssel and a doctoral candidate in the department of movement sciences at Maastricht University. Maastricht, The Netherlands. Dr Kuipers is head of the department of movement sciences at Maastricht University. Address correspondence to Fred Hartgens, MD, The Netherlands Centre for Doping Affairs, PO Box 5014, 2900 EA Capelle aan den IJssel, The Netherlands; e-mail to fred.hartgens@necedo.nl.
University (Maastricht, The Netherlands)

Thirty-five strength athletes participated in this study. Most athletes (28) performed strength training mainly for esthetic purposes and characterized their training regimen as bodybuilding training; only 7 of these subjects participated in bodybuilding contests. Seven participants were competitors: 3 engaged in strength training as a part of their boxing training in addition to using AAS for esthetic reasons, and 4 athletes were principally involved in resistance training for powerlifting competition.

Among the subjects, 19 had decided to begin using AAS to supplement their regular strength training regimen (AAS group). The remaining 16 volunteers who had not used nor were willing to take AAS served as controls (CO group). The physical and training characteristics of both groups are presented in table 1 .

Assessing AAS status. Before entering the study, AAS group members were expected not to have used AAS for at least the previous 3 months. This was verified from information that each subject provided and was corroborated by urinalysis before the start of the study. Interviews revealed that AAS subjects had been drug-free for $8.1 \pm 6.4$ months (range, 3 to 30 months). All but 1 of the AAS group had previously used AAS. The average participant had started using AAS 4.8 years (range, 1 to 14 years) before the study, and the mean number of AAS cycles self-administered was 7.1 (range, 1 to 30 cycles).

Study disclaimer. Although several subjects had received a prescription for steroids from a physician, most AAS users bought the drugs on the black market. Users devised AAS regimens based on information provided by other strength athletes and on their own 


\begin{tabular}{|c|c|c|c|c|c|}
\hline ID Number & AAS Duration (wk) & Drug (route) & Total Used* & ID Number & AAS Duration (wk) \\
\hline 1. $\mathrm{BC} 101$ & 16 & $\begin{array}{l}\text { stanozolol (im) } \\
\text { nandrolone decanoate (im) } \\
\text { metenolone (po) } \\
\text { metenolone (im) } \\
\text { drostanolone (po) } \\
\text { mesterolone (po) }\end{array}$ & $\begin{array}{r}500 \mathrm{mg} \\
350 \mathrm{mg} \\
375 \mathrm{mg} \\
1,400 \mathrm{mg} \\
14 \mathrm{mg} \\
350 \mathrm{mg}\end{array}$ & 10. GR124 & 8 \\
\hline \multirow[t]{2}{*}{ 2. SS102 } & 16 & \multirow{2}{*}{$\begin{array}{l}\text { stanozolol (im) } \\
\text { nandrolone decanoate }(\mathrm{im}) \\
\text { metenolone }(\mathrm{po}) \\
\text { metenolone }(\mathrm{im}) \\
\text { drostanolone }(\mathrm{po}) \\
\text { mesterolone }(\mathrm{po})\end{array}$} & \multirow{2}{*}{$\begin{array}{r}500 \mathrm{mg} \\
350 \mathrm{mg} \\
375 \mathrm{mg} \\
1,400 \mathrm{mg} \\
14 \mathrm{mg} \\
350 \mathrm{mg}\end{array}$} & & \\
\hline & & & & 11. PW125 & 8 \\
\hline \multirow[t]{2}{*}{ 3. MB108 } & 8 & \multirow{2}{*}{$\begin{array}{l}\text { nandrolone decanoate (im) } \\
\text { trenbolone acetate (im) } \\
\text { methandrostenolone (po) } \\
\text { chorionic gonadotropin (im) }\end{array}$} & \multirow{2}{*}{$\begin{array}{r}1,600 \mathrm{mg} \\
228 \mathrm{mg} \\
940 \mathrm{mg} \\
9,000 \mathrm{IU}\end{array}$} & 12. MD139 & 12 \\
\hline & & & & 13. CL148 & 8 \\
\hline 4. JD111 & 12 & $\begin{array}{l}\text { testosterone enanthate (im) } \\
\text { stanozolol (im) } \\
\text { nandrolone decanoate (im) }\end{array}$ & $\begin{array}{r}1,250 \mathrm{mg} \\
700 \mathrm{mg} \\
100 \mathrm{mg}\end{array}$ & \multirow[t]{2}{*}{ 14. FL151 } & \multirow[t]{2}{*}{12} \\
\hline \multirow[t]{2}{*}{ 5. ES112 } & 16 & \multirow{2}{*}{$\begin{array}{l}\text { stanozolol (im) } \\
\text { stanozolol (po) } \\
\text { testosterone propionate (im) } \\
\text { nandrolone decanoate (im) } \\
\text { metenolone (im) }\end{array}$} & $\begin{array}{l}750 \mathrm{mg} \\
450 \mathrm{mg}\end{array}$ & & \\
\hline & & & $\begin{array}{l}375 \mathrm{mg} \\
875 \mathrm{mg} \\
300 \mathrm{mg} \\
\end{array}$ & 15. RD161 & 8 \\
\hline 6. JN113 & 8 & $\begin{array}{l}\text { methandrostenolone (po) } \\
\text { nandrolone decanoate (im) } \\
\text { drostanolone (im) }\end{array}$ & $\begin{array}{l}960 \mathrm{mg} \\
300 \mathrm{mg} \\
300 \mathrm{mg}\end{array}$ & 16. HK401 & 8 \\
\hline \multirow[t]{4}{*}{ 7. GS115 } & \multirow[t]{4}{*}{16} & \multirow{2}{*}{$\begin{array}{l}\text { clenbuterol (po) } \\
\text { stanozolol (po) } \\
\text { nandrolone decanoate (im) } \\
\text { stanozolol ( } \mathrm{po} \text { ) } \\
\text { stanozolol (im) } \\
\text { trenbolone acetate (im) }\end{array}$} & \multirow{2}{*}{$\begin{array}{l}\text { Subject began } \\
\text { stacked use } \\
\text { of these but } \\
\text { did not know } \\
\text { exact doses }\end{array}$} & 17. GT402 & 16 \\
\hline & & & & \multirow[t]{2}{*}{ 18. DV403 } & \multirow[t]{2}{*}{8} \\
\hline & & \multirow{2}{*}{$\begin{array}{l}\text { chorionic gonadotropin (im) } \\
\text { testosterone undecanoate (im) } \\
\text { tamoxifen (po) }\end{array}$} & $\begin{array}{r}\text { Subject said } \\
\text { dosages were }\end{array}$ & & \\
\hline & & & $\begin{array}{l}\text { "high" for } \\
\text { each drug }\end{array}$ & \multirow[t]{3}{*}{ 19. EK404 } & \multirow[t]{3}{*}{12} \\
\hline 8. FB121 & 8 & $\begin{array}{l}\text { nandrolone decanoate (im) } \\
\text { stanozolol (im) } \\
\text { chorionic gonadotropin (im) }\end{array}$ & $\begin{array}{r}2,000 \mathrm{mg} \\
750 \mathrm{mg} \\
13,500 \mathrm{IU}\end{array}$ & & \\
\hline 9. RT122 & 16 & $\begin{array}{l}\text { stanozolol (po) } \\
\text { methandrostenolone (po) } \\
\text { testosterone heptilate (im) }\end{array}$ & $\begin{array}{l}1,080 \mathrm{mg} \\
1,240 \mathrm{mg} \\
3,000 \mathrm{mg}\end{array}$ & & \\
\hline
\end{tabular}

AAS = androgenic-anabolic steroid; im = intramuscular; po = oral

insights and beliefs. Table 2 presents the details of AAS use in participants. Readers should note that the investigators did not provide AAS, that researchers did not attempt to influence which AAS was used, and the researchers did not have any role in AAS administration.

Study design. We conducted a nonblinded study that was divided in three experiments to investigate the objectives set (figure 1).

Experiment 1: Total body composition and anthropometry. Experiment 1 was designed to investigate changes of body composition and anthropometric measurements in strength athletes induced by self-ad- 
Drug (route)

Total Used *

methandrostenolone ( $\mathrm{po}$ )

mesterolone (po)

metenolone (im)

nandrolone decanoate (im)

testosterone (phenyl-) propionate

isohexanoate (im)

trenbolone acetate $(\mathrm{im})$

stanozolol (im)

boldenone (im)

stanozolol (po)

mesterolone (po)

metenolone (im)

oxymetholone (po)

nandrolone decanoate (im)

nandrolone decanoate (im)

stanozolol (po)

stanozolol (im)

testosterone enanthate (im)

testosterone cypionate (im)

chorionic gonadotropin (im)

methandrostenolone (po)

testosterone cypionate (im)

trenbolone acetate (im)

chorionic gonadotropin (im)

methandrostenolone (po)

metenolone ( $\mathrm{po}$ )

mesterolone (po)

stanozolol (po)

oxymetholone ( $\mathrm{po}$ )

nandrolone decanoate (im)

clenbuterol (po)

testosterone enanthate (im)

testosterone cypionate (im)

drostanolone (im)

tanozolol (im)

stanozolol (im)

testosterone (im)

clenbuterol ( $\mathrm{po}$ )

oxymetholone (po)

chorionic gonadotropin (im)

tamoxifen (po)
$560 \mathrm{mg}$

$1,400 \mathrm{mg}$

$800 \mathrm{mg}$

$400 \mathrm{mg}$

$1,750 \mathrm{mg}$

$602 \mathrm{mg}$

$250 \mathrm{mg}$

$300 \mathrm{mg}$

$420 \mathrm{mg}$

$5,600 \mathrm{mg}$

$1,600 \mathrm{mg}$

$3,500 \mathrm{mg}$

$1,625 \mathrm{mg}$

$2,600 \mathrm{mg}$

$1,036 \mathrm{mg}$

$850 \mathrm{mg}$

$3,750 \mathrm{mg}$

$5,000 \mathrm{mg}$

$4,500 \mathrm{IU}$

$980 \mathrm{mg}$

$750 \mathrm{mg}$

$880 \mathrm{mg}$

$4,500 \mathrm{IU}$

$1,115 \mathrm{mg}$

$1,850 \mathrm{mg}$

$675 \mathrm{mg}$

$2,170 \mathrm{mg}$

$1,225 \mathrm{mg}$

$4,400 \mathrm{mg}$

$1.68 \mathrm{mg}$

$2,500 \mathrm{mg}$

$1,000 \mathrm{mg}$

$300 \mathrm{mg}$

$1,200 \mathrm{mg}$

$1,150 \mathrm{mg}$

$5,500 \mathrm{mg}$

$1 \mathrm{mg}$

$1,900 \mathrm{mg}$

$1,500 \mathrm{IU}$

$440 \mathrm{mg}$ ministered AAS. Body composition and dimensions were assessed by taking skinfold thicknesses and circumferences, respectively. Measurements were taken before the start of AAS use (baseline) and after 8 weeks of AAS use. In all AAS users, measurements were also taken 6 weeks after drug cessation, regardless of the length of AAS self-administration. In controls, the same measurements were done at the start of the study and after 8 weeks of strength training.

Experiment 2: Regional alterations of body composition. Eleven strength athletes (6 AAS, $5 \mathrm{CO}$ ) from experiment 1 were randomly selected to participate in experiment 2 . Subjects' body composition was determined with dual-energy $x$-ray absorptiometry (DEXA), in addition to the regular body composition and anthropometric measurements taken in experiment 1 . In 6 strength athletes, we performed DEXA measurements at baseline and after 8 weeks of AAS self-administration. In 5 controls, body composition measurements by DEXA were carried out only at the start of the study.

Experiment 3: Impact of duration of AAS self-administration. Before the start of the study we divided the AAS users from experiment 1 into two subgroups based on their intended AAS course duration. Nine subjects had decided to take these drugs for 8 weeks (shortAAS), while the remaining 10 athletes intended to use AAS for 12 to 16 weeks (long-AAS). Anthropometric measurements and determination of body composition were carried out at baseline, at the end of the drug administration, and 6 weeks after AAS withdrawal.

Measurements. Height was measured with an anthropometer. Body weight was determined to the nearest $0.1 \mathrm{~kg}$ using a bascule.

Skinfolds were measured with a Holtain caliper at eight sites: biceps, triceps, subscapular, pectoral, suprailiac, umbilicus, thigh, and calf. All measurements were taken twice by an experienced investigator. The mean of both measurements was recorded. To avoid interobserver error, a single investigator took measurements in the same subject throughout the study. The percentage of fat was estimated from skinfold measurements according to the method of Durnin and Wormersley. ${ }^{4}$ Lean body mass and fat mass were calculated using body weight and percentage fat.

Eleven circumference measurements at 10 sites were taken with a tape measure: neck, thorax, waist, buttocks, upper arm (relaxed), upper arm (contracted), forearm, wrist, thigh (just below the buttocks), thigh (two-thirds the distance from the major trochanter and lateral site of the knee joint), and calf. An experienced investigator took all measurements twice, and the mean of both measurements was recorded.

continued 


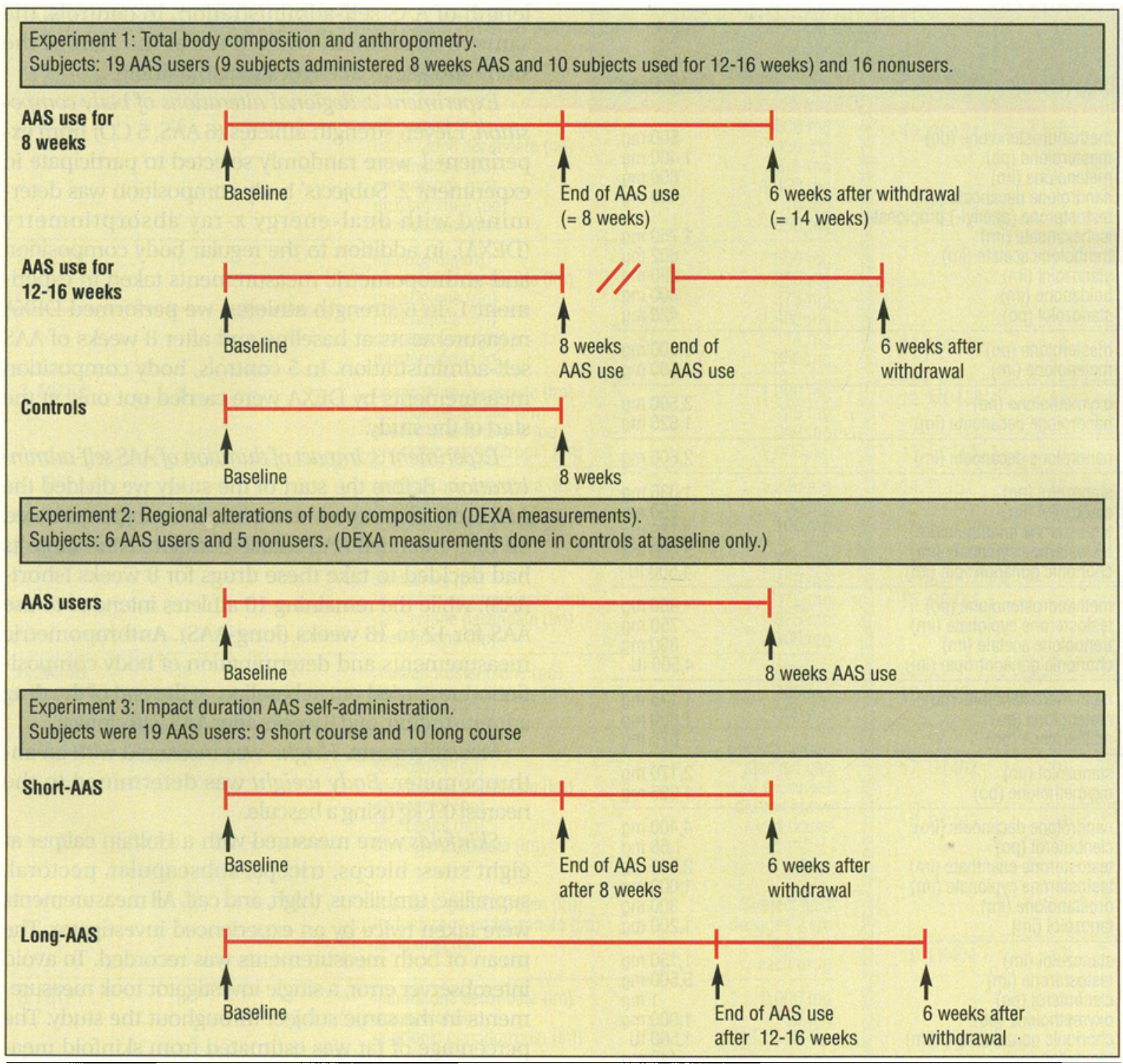

FIGURE 1. Overview of the experiments of AAS use and body changes.

$\Lambda=$ indicates measurement; $/ /=$ indicates that the duration of AAS self-administration varied between subjects from 12 to 16 weeks; AAS $=$ androgenic-anabolic steroids; $D E X A=$ dual energy $x$-ray absorptiometry

Total and regional body composition measurements were performed using DEXA apparatus (DPX-L, Lunar Corp, Madison, Wisconsin) at a fast scan speed with a whole-body resolution of $4.8 \times 9.6 \mathrm{~mm}$. To determine the composition of regional body segments and limbs, DEXA measurements were divided in discrete values for arms, legs, and trunk on the basis of anatomic landmarks. As determined by Mazess et al, ${ }^{5}$ the precision of these measurements is $1.5 \%$ for the arms, $0.8 \%$ for the legs, and $1.1 \%$ for the trunk. Total mass, fat mass, and bone-free lean mass were determined using Lunar software (version $1.3 \mathrm{z}$ ) for each body region (arms, continued 
trunk, and legs).

Monitoring and compliance. Information about the subjects' training and nutritional habits was collected before the start of the study and in week 8. Subjects' nutritional intake was determined with a 3-day diary. Training data were obtained by a 1 -week log. For longAAS strength athletes, nutritional and training data were also obtained at the end of the AAS administration. In all AAS users, these data were collected 6 weeks after drug cessation.

To gauge subjects' compliance with drug administration or abstinence before the start of the study and after 8 weeks, urine samples from all athletes were obtained for drug evaluation purposes (Netherlands Institute for Drug and Doping Research, Utrecht, The Netherlands). For the long-AAS group, urine samples were taken at the end of the drug-use period. All AAS-using strength athletes submitted urine samples 6 weeks after drug withdrawal. From all samples taken, about one-third were randomly chosen for analysis.

Statistical analysis. Descriptive statistics were calculated for all measurements using Stat-View software (Abacus Concepts, Berkeley, California, 1994). Data are presented as mean plus or minus standard deviation (SD). The Mann-Whitney $\mathrm{U}$-test was used to compare differences in the observed changes between groups. The Wilcoxon signed rank test was used for analysis of intragroup changes after drug withdrawal (experiment 1) and for DEXA $P<0.01 ;{ }^{* * *}=P<0.001$.

\begin{tabular}{|c|c|c|c|c|}
\hline Segment & Group & Baseline & $8 W k$ & $\begin{array}{l}6 \text { Wk } \\
\text { Postwithdrawal }\end{array}$ \\
\hline Neck & $\begin{array}{l}\text { AAS } \\
\text { Control }\end{array}$ & $\begin{array}{l}39.2 \pm 1.9 \\
39.6 \pm 2.2\end{array}$ & $\begin{array}{l}40.5 \pm 2.1 \# \# \# \\
39.6 \pm 2.2\end{array}$ & $\begin{array}{l}40.2 \pm 1.9 * * \\
\text { na }\end{array}$ \\
\hline Thorax & $\begin{array}{l}\text { AAS } \\
\text { Control }\end{array}$ & $\begin{array}{l}95.8 \pm 6.5 \\
98.5 \pm 7.3\end{array}$ & $\begin{array}{l}98.4 \pm 6.4 \\
99.9 \pm 7.2\end{array}$ & $\begin{array}{l}98.1 \pm 6.5^{\star \star} \\
\text { na }\end{array}$ \\
\hline Waist & $\begin{array}{l}\text { AAS } \\
\text { Control }\end{array}$ & $\begin{array}{l}84.8 \pm 7.1 \\
86.8 \pm 5.4\end{array}$ & $\begin{array}{l}86.3 \pm 7.1 \\
87.1 \pm 6.4\end{array}$ & $\begin{array}{l}85.1 \pm 7.2 \\
\text { na }\end{array}$ \\
\hline Buttocks & $\begin{array}{l}\text { AAS } \\
\text { Control }\end{array}$ & $\begin{array}{l}98.7 \pm 5.6 \\
99.3 \pm 4.8\end{array}$ & $\begin{array}{l}100.6 \pm 5.5 \\
100.0 \pm 4.9\end{array}$ & $\begin{array}{l}100.0 \pm 5.5^{* *} \\
\text { na }\end{array}$ \\
\hline Upper arm (relaxed) & $\begin{array}{l}\text { AAS } \\
\text { Control }\end{array}$ & $\begin{array}{l}36.6 \pm 3.0 \\
38.9 \pm 3.7\end{array}$ & $\begin{array}{l}38.5 \pm 3.3 \# \# \# \\
39.0 \pm 3.8\end{array}$ & $\begin{array}{l}37.8 \pm 3.4^{* *} \\
\text { na }\end{array}$ \\
\hline Upper arm (contracted) & $\begin{array}{l}\text { AAS } \\
\text { Control }\end{array}$ & $\begin{array}{l}40.1 \pm 3.3 \\
42.0 \pm 3.6\end{array}$ & $\begin{array}{l}41.6 \pm 3.1 \# \# \\
42.4 \pm 3.7\end{array}$ & $\begin{array}{l}41.5 \pm 3.5^{\star \star \star} \\
\text { na }\end{array}$ \\
\hline Forearm & $\begin{array}{l}\text { AAS } \\
\text { Control }\end{array}$ & $\begin{array}{l}31.3 \pm 1.9 \\
32.8 \pm 2.8\end{array}$ & $\begin{array}{l}32.4 \pm 2.1 \text { \#\#\# } \\
32.7 \pm 2.2\end{array}$ & $\begin{array}{l}32.6 \pm 2.8^{\star *} \\
\text { na }\end{array}$ \\
\hline Wrist & $\begin{array}{l}\text { AAS } \\
\text { Control }\end{array}$ & $\begin{array}{l}18.2 \pm 1.0 \\
18.3 \pm 0.8\end{array}$ & $\begin{array}{l}18.5 \pm 1.1 \# \\
18.3 \pm 0.9\end{array}$ & $\begin{array}{l}18.3 \pm 1.0 \\
\text { na }\end{array}$ \\
\hline Thigh (upper) & $\begin{array}{l}\text { AAS } \\
\text { Control }\end{array}$ & $\begin{array}{l}61.5 \pm 5.5 \\
63.4 \pm 4.6\end{array}$ & $\begin{array}{l}63.7 \pm 5.1 \# \# \\
63.4 \pm 4.8\end{array}$ & $\begin{array}{l}62.7 \pm 5.1^{*} \\
\text { na }\end{array}$ \\
\hline Thigh (lower) & $\begin{array}{l}\text { AAS } \\
\text { Control }\end{array}$ & $\begin{array}{l}50.0 \pm 3.4 \\
51.8 \pm 3.3\end{array}$ & $\begin{array}{l}52.2 \pm 4.4 \# \# \\
51.6 \pm 2.9\end{array}$ & $\begin{array}{l}50.8 \pm 3.6^{\star} \\
\text { na }\end{array}$ \\
\hline Calf & $\begin{array}{l}\text { AAS } \\
\text { Control }\end{array}$ & $\begin{array}{l}38.7 \pm 2.2 \\
40.2 \pm 2.6\end{array}$ & $\begin{array}{l}39.6 \pm 2.2 \text { \#\#\# } \\
40.2 \pm 2.7\end{array}$ & $\begin{array}{l}39.1 \pm 2.2^{*} \\
\text { na }\end{array}$ \\
\hline
\end{tabular}

All values are expressed in grams as the mean \pm standard deviation. Mann Whitney test for interaction was used to test interaction, the difference between change in control group and AAS group; \# $=P_{<}$ $0.05 ; \#=P<0.01 ; \# \#=P<0.001$.

Wilcoxon test was used to compare differences between postwithdrawal and baseline; ${ }^{*}=P<0.05 ;{ }^{* *}=$

AAS = androgenic-anabolic steroid; na = data not available

measurements of subjects taking AAS (experiment 2) The level of significance was set at 0.05 for all analyses.

\section{Results}

Total body composition and anthropometry. After 8 weeks, the AAS group had a significant increase of approximately $4.5 \mathrm{~kg}$ in body weight and lean body continued 


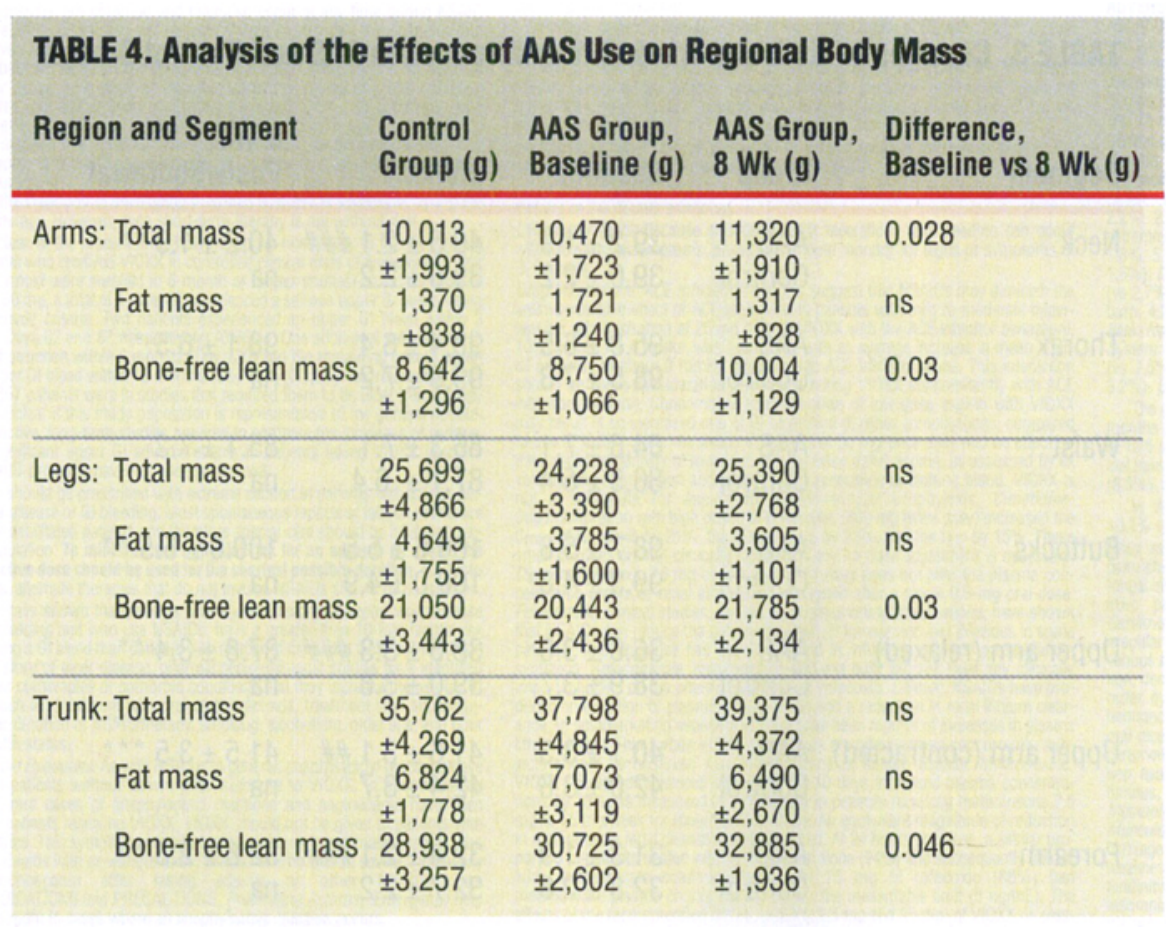

All values are expressed in grams as the mean \pm standard deviation. Paired AAS group data were analyzed using the Wilcoxon signed rank test at 0.05 significance.

AAS = androgenic-anabolic steroid; $\mathrm{ns}=$ not significant

mass, whereas the controls exhibited no significant change. Mean body weight increased from $84.0 \pm 9.9$ to $88.4 \pm 10.7 \mathrm{~kg}$, and lean body mass rose from $69.6 \mathrm{~kg}$ to $74.1 \mathrm{~kg}$. The percentage of fat during AAS use was significantly reduced from $17.0 \%$ to $16.0 \%$, but this was not reflected in a loss of fat mass. Gains in body weight and lean body mass were still partly present 6 weeks after drug withdrawal (table 3 ). In both groups, no significant increase in skinfold measurements or their sums were observed during the study.

In the AAS group, increases in the circumferences of neck, upper arm, forearm, wrist, thigh, and lower leg were significantly larger than in the control group. Circumference changes of the thorax, waist, and buttocks did not reach significance compared with those of controls. Although the circumferences were slightly reduced after drug withdrawal, they were still increased compared with baseline levels (see table 3 ).

Regional body composition changes. Baseline DEXA measurements of body segment composition were not significantly different between the AAS users and control athletes. After 8 weeks of AAS use, the weight of the arm was sig. nificantly increased, but the weight of the trunk and legs remained unchanged. Bone-free lean masses of the arms, trunk, and legs were significantly greater during AAS use than at baseline (table 4). AAS use did not affect the fat mass of the arms, legs, and trunk. Total bone mineral density and bone mineral content did not change significantly.

Length of AAS regimen. No significant differences were observed in body weight, percentage of fat, fat mass, lean body mass, and circumferences between short-AAS and longAAS users. Similarly, these parameters were not significantly different between groups 6 weeks after drug withdrawal .

Training, nutrition, and compliance. Throughout the entire study, weekly training hours and regimens between groups in the three experiments remained comparable. The same was true for nutritional intake. Urinalysis revealed compliance within the groups: Urine samples from the AAS users contained steroid metabolites, and samples of the CO group did not.

\section{Discussion}

AAS-induced changes. Experienced strength athletes who use a self-composed course of AAS for 8 weeks exhibited increased total body weight and total lean body mass compared with those who did strength training alone; total fat mass remained unaffected. Among regional body segments (arms, legs, and trunk) in these athletes, only arm weight increased significantly. However, lean mass was significantly increased in all regional body parts, and these 
findings are reflected in the increased arm and leg circumferences. Increases were for the most part still present 6 weeks after drug cessation. These findings are relevant because until now scientific data concerning AAS effects on anthropometry and body composition were equivocal.

From cross-sectional studies, one might infer that AAS-using strength athletes differ in body composition from nonusing athletes. ${ }^{6.7}$ These observations have been supported by longitudinal studies. The most pronounced effects on body weight and lean body mass were found in athletes who self-administered several AAS simultaneously in high doses. ${ }^{8,9}$ Such regimens may increase body weight by an average of about $5.2 \mathrm{~kg}$ (11.4 lb). Lean body mass increases may be even larger, especially after long-term administration. ${ }^{8.10}$

The present study indicates that the use of a single AAS seems to induce less remarkable effects than multiple-drug regimens. ${ }^{9,11-13}$ This is in line with an observation of Forbes, ${ }^{14}$ who had previously described a positive relationship between the total dose of AAS used and the increase of lean body mass. On the other hand, research ${ }^{9.11 .15 .16}$ that compared the effects of different doses of a single AAS indicates that such a relationship might be less ambiguous than that proposed by Forbes.

Previous methods and DEXA. One factor that may have contributed to the consistent results is the method used to determine body composition. No alterations were seen in studies ${ }^{17-20}$ that investigated body composition with underwater weighing. In these studies, the effect of a single drug was analyzed, but, unfortunately, no reports are available on underwater weighing assessment of body composition in multipledrug-using athletes. Although previous studies assessed the traditional two-compartment model either with skinfold measurements or with underwater weighing, our study employed DEXA to assess a threecompartment model for body composition alterations.

DEXA was designed primarily to estimate bone mineral content and density in humans. ${ }^{21}$ Determination of body composition by DEXA is based on the difference in attenuation of $x$-rays between soft and bone tissue as well as the difference in attenuation between fat and lean tissue. This method provides a three-compartment model that divides the body into total bone mineral content, bone-free lean mass, and fat mass. An advantage of DEXA over hydrodensitometry is that
DEXA appears to be less affected by hydration status. $^{21,22}$ This may be an important advantage in estimating body composition in athletes since hydration status may be affected by training.

Assessing regional body changes. Because of the documented DEXA accuracy for total and regional body dimension measurement ${ }^{5,23}$ and the AAS potential for inducing regional changes in body composition, strength athletes may have particular interest in both DEXA and AAS. DEXA measurements in this study reveal an increase in bone-free lean mass of all body parts measured in bodybuilders using AAS. One interesting finding was that the increase in the bonefree mass of the arms was approximately twice that in the leg or trunk ( $14 \%$ versus about $7 \%$ ). This finding could not be attributed to differences in training regimens because the training diaries revealed comparable regimens in both groups. On the other hand, in another study ${ }^{16}$ the administration a single anabolic steroid (nandrolone decanoate) induced the largest gain of bone-free lean mass in the legs and trunk. Since both studies are complementary, one possibility might be that different AAS regimens may affect specific areas more than others.

Although evidence has shown that AAS increases lean body mass, ${ }^{24-26}$ no one has determined what constitutes the change in lean mass. Previous research associated AAS-induced lean body mass alterations with increments of blood volume and water retention. ${ }^{12,27,28}$ In a recent study (W. Van Marken Lichtenbelt etal, manuscript submitted for publication), we were able to investigate the effects of AAS on body composition with a four-compartment model. That study revealed that total body water increased from AAS use but that the ratio between extracellular and intracellular water remained unaffected. In addition, lean mass hydration status was not influenced by AAS. Thus, the most likely explanation for the gain of lean mass can be explained by muscle increase rather than from water retention.

Dispelling steroid-use myths. Among strength athletes, long-term AAS administration is generally believed to produce better results than short-term use. Additionally, these athletes claim that after long-term AAS use the gains in body composition parameters will persist longer than after short-term administration. These beliefs are not supported by the present study. The effects on body composition and anthropocontinued 
metric variables after short- and long-term AAS use were comparable. The same applied for residual changes seen after drug withdrawal. Therefore, we conclude that duration of AAS administration in itself is not the key factor for optimal and longstanding effects on body composition.

Health hazards. From a medical point of view, long-term AAS administration is of great concern..$^{29}$ Several investigators ${ }^{9,30,31}$ have reported that AAS use induces an unfavorable lipoprotein profile and thus increases the risk for cardiovascular diseases. Recent research has demonstrated that duration of AAS use has a strong impact on the lipoprotein profile changes. ${ }^{33}$ Extended AAS administration provokes more dramatic side effects on the lipoprotein profile compared with short-term AAS use, and the time required for full reversal of these side effects was prolonged after longterm use (F. Hartgens et al, manuscript submitted for publication). Consequently, long-term users are more prone to have cardiovascular events.

Most strength athletes are convinced that after drug abstinence the effects on body composition will persist for some time. Our results show that 6 weeks after drug withdrawal the changes of circumferences were still significantly increased over baseline values, though slight decreases were seen compared with values at the

\section{REFERENCES}

1. International Olympic Committee: 1997 Statistics of the International Olympic Committee accredited laboratories. International Olympic Committee, Lausanne, Switzerland, 1998

2. Vogels T, Brugman E, Coumans B, et al: Lijf, sport en middelen. Nederlands Instituut voor Praeventieve Gezondheidszorg. Leiden, The Netherlands, TNO, 1994

3. Yesalis CE: Anabolic Steroids in Sport and Exercise, ed 2. Champaign, IL, Human Kinetics, 2000

4. Durnin JVGA, Wormersley J: Body fat assessed from total density and its estimation from skinfold thickness: measurements on 481 men and women aged from 16 to 72 years. Br J Nutr 1974;32:77-97

5. Mazess RB, Barden HS, Bisek JP, et al: Dual-energy x-ray absorptiometry for total body and regional bone mineral and soft tissue composition. Am J Clin Nutr 1990;51:1106-1112

6. Hartgens F, Kuipers H, Wijnen J, et al: Body composition, cardiovascular risk factors and liver function in long-term androgenic-anabolic steroids using bodybuilders three months after drug withdrawal. Int J Sports Med 1996; 17(6) 429-433

7. Kouri EM, Pope HJ Jr, Katz DL, et al: Fat-free mass index in users and nonusers of anabolic-androgenic steroids. Clin J Sports Med 1995;5(4):223-228 end of AAS use. Many AAS users take, on average, two to three courses in 1 year. ${ }^{6.32}$ Their approach is to start a new AAS course when they assume that the side effects have disappeared but the desired effects on body composition and strength are still present to some extent. There are indications that such procedures may be effective, ${ }^{6}$ but the effects of such procedures on health status are unknown and remain of great concern.

\section{Summary}

This study has demonstrated that in athletes the administration of a self-composed, 8-week course of AAS combined with strength training increased body weight, lean body mass, and limb circumferences more than did strength training alone. Arm mass, but not trunk and leg mass, was increased by AAS use. DEXA analysis showed that AAS stimulated the bonefree lean mass of all body parts, but the effects on the arms were the most pronounced. Fat mass was not affected by AAS use. The increments in total body weight, lean body mass, and girths were still largely evident 6 weeks after drug withdrawal. There was no relationship between the duration of AAS use and the extent of changes in body composition and anthropometric variables. Psy

8. Alen M, Hakkinen K, Komi PV: Changes in neuromuscular performance and muscle fiber characteristics of elite power athletes self-administering androgenic and anabolic steroids. Acta Physiol Scand 1984;122(4):535-544

9. Kuipers H, Wijnen JA, Hartgens F, et al: Influence of anabolic steroids on body composition, blood pressure, lipid profile and liver function in bodybuilders. Int J Sports Med $1991 ; 12(4): 413-418$

10. Alen $M$, Hakkinen $K$ : Physical health and fitness of an elite bodybuilder during $l$ year of self-administration of testosterone and anabolic steroids: a case study. Int J Sports Med 1985;6(1):24-29

11. Friedl KE, Dettori JR, Hannan CJ, et al: Comparison of the effects of high dose testosterone and 19-nortestosterone to a replacement dose of testosterone on strength and body composition in normal men. J Steroid Biochem Mol Biol 1991;40(4-6):607-612

12. Hervey GR, Hutchinson I, Knibbs AV, et al: 'Anabolic' effects of methandienone in men undergoing athletic training. Lancet 1976;2(7988):699-702

13. Win-May M, Mya-Tu M: The effect of anabolic steroids on physical fitness. J Sports Med Phys Fitness 1975;15(3):266-271

14. Forbes GB: The effect of anabolic steroids on lean body mass: the dose response curve. Metabolism 1985;35(6):571-573

continued 
15. Bhasin S, Storer TW, Berman N, et al: The effects of supraphysiologic doses of testosterone on muscle size and strength in normal men. N Engl J Med 1996;335(1):I-7

16. Hartgens F, Van Marken Lichtenbelt W, Ebbing S, et al: body composition and anthropometry in bodybuilders: regional changes due to nandrolone decanoate administration. Int J Sports Med, to be published

17. Casner SJ, Early RG, Carlson BR: Anabolic steroid effects on body composition in normal young men. J Sports Med Phys Fitness 1971;11:98-103

18. Crist DM, Stackpole PJ, Peake GT: Effects of androgenic-anabolic steroids on neuromuscular power and body composition. J Appl Physiol 1983;54(2):366-370

19. Fahey TD, Brown CH: The effects of an anabolic steroid on the strength, body composition, and endurance of college males when accompanied by a weight training program. Med Sci Sports 1973;5(4):272-276

20. Golding LA, Freydinger JE, Fishel SS: Weight, size, and strength unchanged with steroids. Phys Sportsmed 1974; 2(6):39-43

21. Lohman T: Advances in Body Composition Assessment. Champaign, IL, Human Kinetics, 1992

22. Heyward VH: Evaluation of body composition: current issues. Sports Med 1996;22(3):146-156

23. Fuller NJ, Laskey MA, Elia M: Assessment of the composition of major body regions by dual-energy x-ray absorptiometry (DEXA), with special reference to limb muscle mass. Clin Physiol 1992;12(3):253-266

24. Lovejoy JC, Bray GA, Bourgeois MO, et al: Exogenous androgens influence body composition and regional body fat distribution in obese postmenopausal women: a clinical research center study. J Clin Endocrinol Metab 1996;81(6): 2198-2203

25. Lovejoy JC, Bray GA, Greeson CS, et al: Oral anabolic steroid treatment, but not parenteral androgen treatment, decreases abdominal fat in obese, older men. Int J Obes Relat Metab Disord 1995;19(9):614-624

26. Marin P, Holmang S, Jonsson L, et al: The effects of testosterone treatment on body composition and metabolism in middle-aged obese men. Int J Obes Relat Metab Disord 1992;16(12):991-997

27. Hervey GR, Knibbs AV, Burkinshaw L, et al: Effects of methandienone on the performance and body composition of men undergoing athletic training. Clin Sci 1981; 60(4):467-461

28. Holma P: Effect of an anabolic steroid (methandienone) on central and peripheral blood flow in well-trained male athletes. Ann Clin Res 1977;9:215-221

29. Wilson JD: Androgen abuse by athletes. Endocr Rev 1988; 9(2) 181-199

30. Alen M, Rahkila P, Marniemi J: Serum lipids in power athletes self-administering testosterone and anabolic steroids. Int J Sports Med 1985;6(3):139-144

31. Lenders JW, Demacker PN, Vos JA, et al: Deleterious effects of anabolic steroids on serum lipoproteins, blood pressure, and liver function in amateur body builders. Int J Sports Med 1988;9(1):19-23

32. DeBoer A, van Haren SF, Hartgens F, et al: Onderzoek naar het gebruik van prestatieverhongende middelen bij bodybuilders in Nederland. Nederlands Centrum voor Dopingvraagstukken, Universiteit Utrecht, Rotterdam, The Netherlands, 1996
The level of performance is also affected by the particular kind of grafting. Most kidney and liver transplant recipients are able to regain their former physical condition, but this is not true for heart and lung transplant subjects. The latter continue to be affected by heart denervation and altered lung function, which often keeps them out of competition.

\section{Recommendations}

Preventive medical therapy and follow-up measures as well as sport-specific recommendations are needed to allow transplant patients safe athletic participation. Until reliable clinical and epidemiologic studies are performed, low-impact, recreational, noncontact sports are recommended, and high-level competition by transplant patients should be discouraged. PEM

\section{REFERENCES}

1. Markey KL: Stress fractures. Clin Sports Med 1987;6(2): 405-425

2. Nixon JE, Hughes SP, Castro JE: Orthopaedic complications of renal transplantation. J Bone Joint Surg (Br) 1980; 62(4):526

3. Ramsey-Goldman R, Dunn JE, Dunlop DD, et al: Increased risk of fracture in patients receiving solid organ transplants. J Bone Miner Res 1999;14(3):456-463

4. Torg JS, Balduini FC, Zelko RR, et al: Fractures of the base of the fifth metatarsal distal to the tuberosity: classification and guidelines for non-surgical and surgical management. J Bone Joint Surg (Am) 1984;66(2):209-214

5. Lukert BP, Raisz LG: Glucocorticoid-induced osteoporosis: pathogenesis and management. Ann Intern Med 1990; 112(5):352-364

6. Grotz WH, Mundinger FA, Gugel B, et al: Bone mineral density after kidney transplantation: a cross-sectional study in 190 graft recipients up to 20 years after transplantation. Transplantation 1995;59(7):982-986

7. Horber FF, Casez JP, Steiger U, et al: Changes in bone mass early after kidney transplantation. J Bone Miner Res 1994; 9(1):1-9

8. Adachi JD, Olszynski WP, Hanley DA, et al: Management of corticosteroid-induced osteoporosis. Semin Arthritis Rheum 2000;29(4):228-251

9. Takeo $\mathrm{Y}$, Tominaga K, Tsuji H, et al: Spontaneous fracture and osteoporosis following renal transplantation, abstracted (in Japanese). Nippon Seikeigeka Gakkai Zasshi 1989; 63(5):507-513

10. Smets YF, van der Pijl JW, de Fijter JW, et al: Low bone mass and high incidence of fractures after successful simultaneous pancreas-kidney transplantation. Nephrol Dial Transplant 1998;13(5):1250-1255

11. Kalker AJ, Pirsch JD, Heisey D, et al: Foot problems in the diabetic transplant recipient. Clin Transplant 1996;10(6 pt 1):503-510

12. Brukner PD, Khan KM: Clinical Sports Medicine. Sydney, Australia, McGraw-Hill, 1993, p 17 